\title{
補强石造儿關する研究
}

從來の石積 (ヌはブロック積。以下同じ) は目地の 強度が不確賽で主な弱呫となつていた。そこで潰田稔 博士は目地の强度夸確實な計算にのせる篇に \$2. に述 ベる新しい組積工法を提案された。 本䂺究は此の新工法による目地の強度を實驗により求 め，日その計算式学得よ5とするもので市る。

\section{§2. 新工法の說明}

補強方法……目地の強度はモルタルの附着力には原 則として体存せず，慗筋で結合する。郎ち第1圖に示

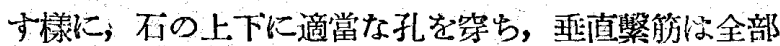
下面の孔へモルタルで少く共積む數日前に取付けて置

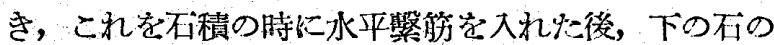
モルタル孔へ押し込む。以上の方法で各不は上下左右 に結合され，モーメント及箾断力に對して安全とな る。

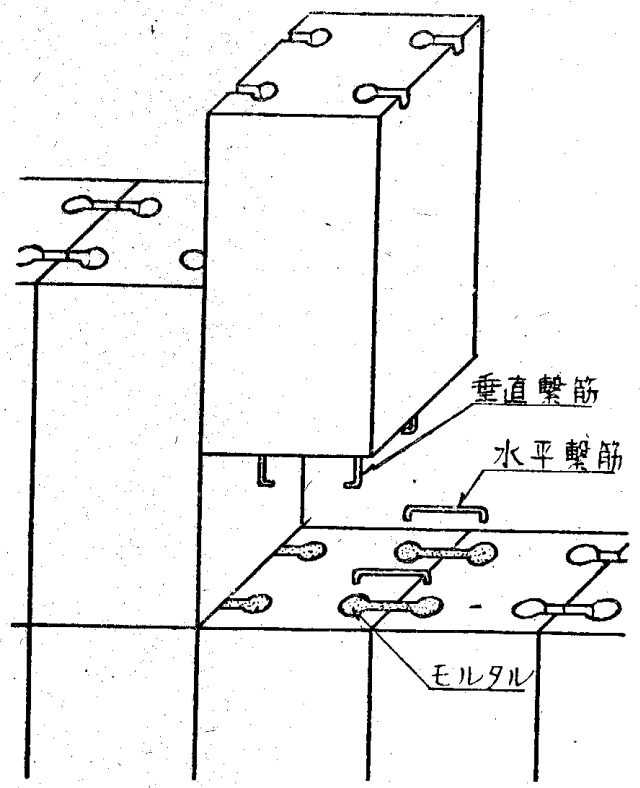

第 1 圖 補强方法

不積形式……不は原則としてている日地」の縱積と する。いも目地とするのは，垂直方向の曲げモーント

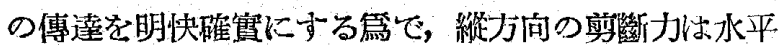
㢣筋により受けること分出來る。又縱積にするのは同

\section{東京大學第一工學部材料研究室}

じ鐵筋量を用ひた場合，平積に較べて曲げモーメント 及水平方向の剪斷力に對する抗力か増大寸る篇であ 㐫る。此の場合には垂直方向の前斷力に對する抗力は 減少するが，實際の建筑物に就て計算を行つて見る と，垂直方向の剪衒力の方が食裕があるので，縱積の 万が合理的であると考へられる。份此の工法によつた 場合の資材の所要量は，15 坪 2 户建の住宅で $1 \mathrm{M}^{2}$ 當 り鋼材 $2.7 \mathrm{~kg}$ ，七メント $7.0 \mathrm{~kg}$ 程度と㐫つて，多少 の增減はあるにしても比較的少量ですむ。

\section{§3. 曲げ試驗}

1) 試驗體

形狀 : 第 2 圖に示す。
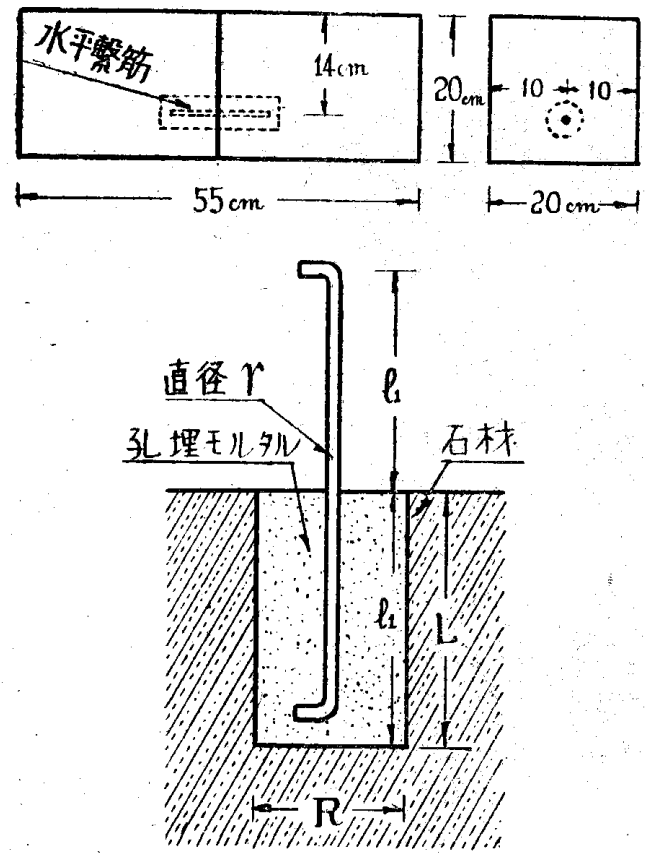

第 2 圖 曲 ゙゙試驗 體

材料:不材一大谷不。區縮強度 $79 \mathrm{~kg} / \mathrm{cm}^{2}$ 。

繫筋一一普通構造用丸鋼及番線。引張強度 40 $\sim 50 \mathrm{~kg} / \mathrm{cm}^{2}$ 。

セメントー一日本ポルトランドセメント。壓

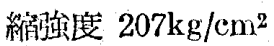

試驗體種類： 試驗體の種類は第 1 表に示す。各種 2 ケ宛製作した。 
第 1 表 曲 ザ試驗能、の種類

\begin{tabular}{|c|c|c|c|c|c|c|c|c|c|c|}
\hline 系 & 試 驗 日 的 & $\begin{array}{l}\text { 陚驗體 } \\
\text { 潘號 }\end{array}$ & $\begin{array}{l}\text { モルタ } \\
\text { ル調合 }\end{array}$ & $\begin{array}{l}\text { 鐵笩地埋 } \\
\text { 资さ } \\
\mathrm{I}_{1} \mathrm{~cm} \\
\end{array}$ & 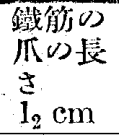 & 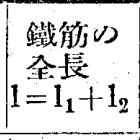 & $\begin{array}{ll}\text { 鐵 } & \text { 伤 } \\
\text { 牟 } \\
\text { r mm }\end{array}$ & $\begin{array}{l}\text { 势 } \\
\text { 梁 } \mathrm{e} \\
\mathrm{L}\end{array}$ & $\begin{array}{l}\text { 热 } \\
\text { 得 } \\
\mathrm{R} \mathrm{cm}\end{array}$ & $\begin{array}{l}\text { 孔 } \\
\text { 数 } \\
\text { 知 }\end{array}$ \\
\hline \multirow{3}{*}{$I$} & \multirow{3}{*}{ 槧笳の埋达長さ凹影響 } & 1 & $1: 3$ & 8 & 2 & 10 & 6 & 9 & 4 & 2 \\
\hline & & 2 & " & 6 & " & 8 & "I & " & " & $"$ \\
\hline & & 3 & " & 4 & $y$ & 6 & " & $"$ & " & $" 1$ \\
\hline \multirow{3}{*}{ II } & \multirow{3}{*}{ 慗筋の爪の影響 } & 4 & " & 6 & $"$ & 8 & " & 7 & $" 1$ & 1 \\
\hline & & 5 & $"$ & " & 1 & 7 & $"$ & "l & $"$ & $"$ \\
\hline & & 6 & $"$ & " & 0 & 6 & " & $"$ & $"$ & $"$ \\
\hline \multirow{3}{*}{ II } & \multirow{3}{*}{ 慗筋の傯の影響 } & 7 & " & ") & 2 & 8 & 9 & " & "1 & 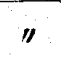 \\
\hline & & 4 & $" \prime$ & " & $"$ & $" \prime$ & 6 & " & " & $"$ \\
\hline & & 8 & " & " & $"$ & $"$ & 4 & 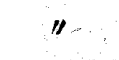 & ") & $"$ \\
\hline \multirow{3}{*}{ N } & \multirow{3}{*}{ 孔の深さの影響 } & 9 & " & 8 & "I & 10 & 9 & 9 & " & $\overline{\prime \prime}$ \\
\hline & & 7 & " & 6 & " & 8 & " & 7 & נ) & $"$ \\
\hline & & 10 & $"$ & 4 & $"$ & 6 & " & 5 & 11 & $"$ \\
\hline \multirow{3}{*}{1} & \multirow{3}{*}{ モルタル諴合の影響 } & 11 & $1: 1$ & 6 & " & 8 & 6 & 7 & $"$ & 1 \\
\hline & & 12 & $1: 2$ & " & $"$ & $"$ & $"$ & $"$ & " & , \\
\hline & & 4 & $1: 3$ & " & $n-$ & " & $" 1$ & " & " & $"$ \\
\hline ПI & 補强しない目地 & 13 & $"$ & & 目 & 地 & 約 & $1 \mathrm{~cm}$ & & \\
\hline
\end{tabular}

2) 試驗方法

試羷方法の大要性第 3 圖に示す。

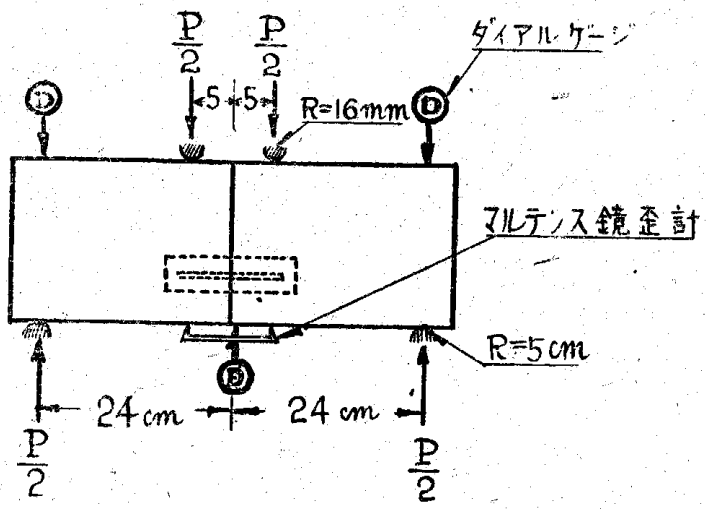

第3 圖 曲 ザ試驗方法

3) 試驗結果

第 2 表 第 5 9 圖の符號の說明

\begin{tabular}{|c|c|}
\hline & 月最大強度 \\
\hline$\ldots$ & 材令1 个月最大強度 \\
\hline$-\cdots$ & 材令 34月降伏奌強度 \\
\hline$\cdots$ & 材令1 月月降仗点强度 \\
\hline - & 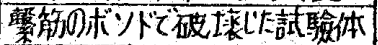 \\
\hline - & 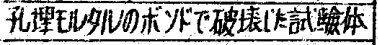 \\
\hline$x$ & 石材が破埭した試驗体 \\
\hline
\end{tabular}

試驗結果は 第 2 表及 4 9 圖に示す。 ここで降伏點 虫引張側目地 の開き $\lambda か$ $0.5 \mathrm{~mm}$ にな つを時とし

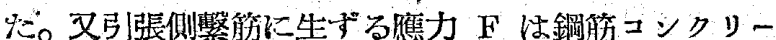
トの通常の略算式 $\left(\mathrm{j}=\frac{7}{8} \mathrm{~d}, \mathrm{~F}=\frac{\mathrm{M}}{\mathrm{j}}\right)$ Kより求めた。

份，補強してない目地の No. 13 は，標準的な補強

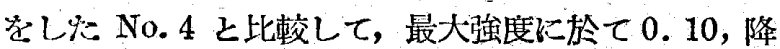

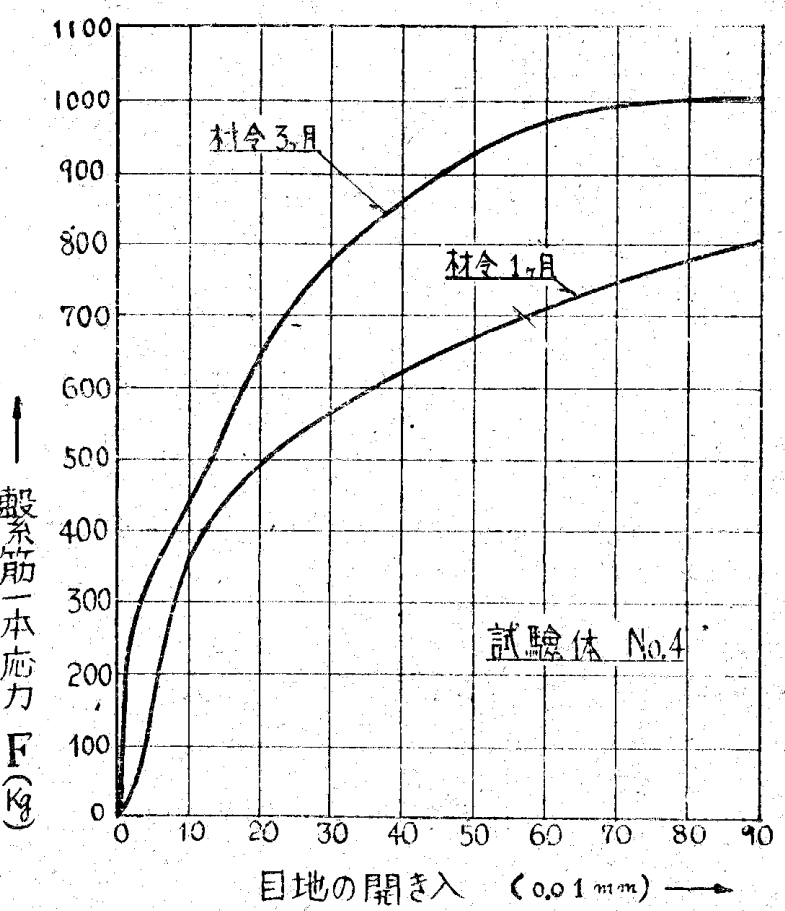

第4 圖 曲げ試驗の變形狀態の 1 例 


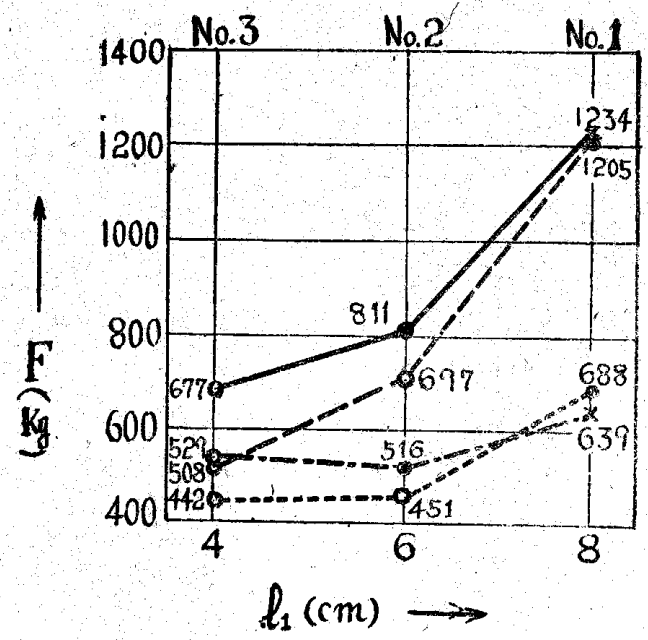

第 5 圖 系 I

·擊筋の埋达長さ $\left(\mathrm{l}_{1}\right)$ 之强度 (F)

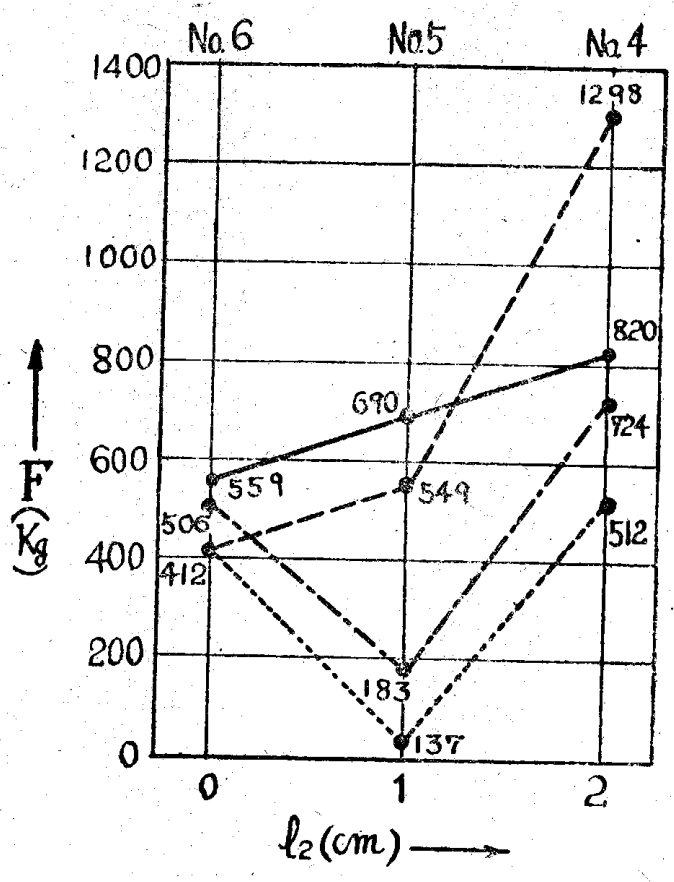

第 6 圖 系 II

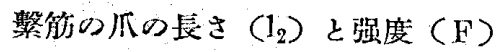

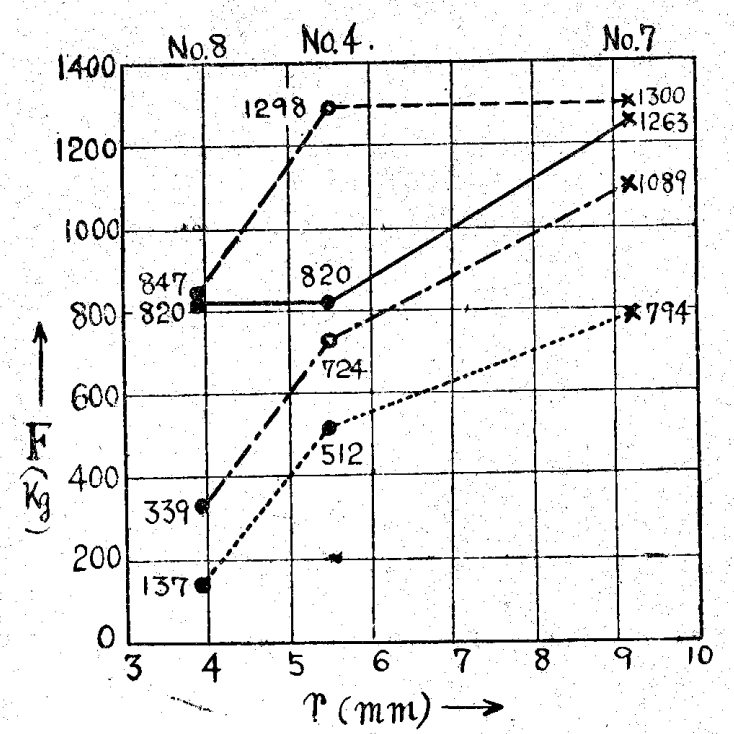

第 7 圖系 II

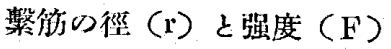

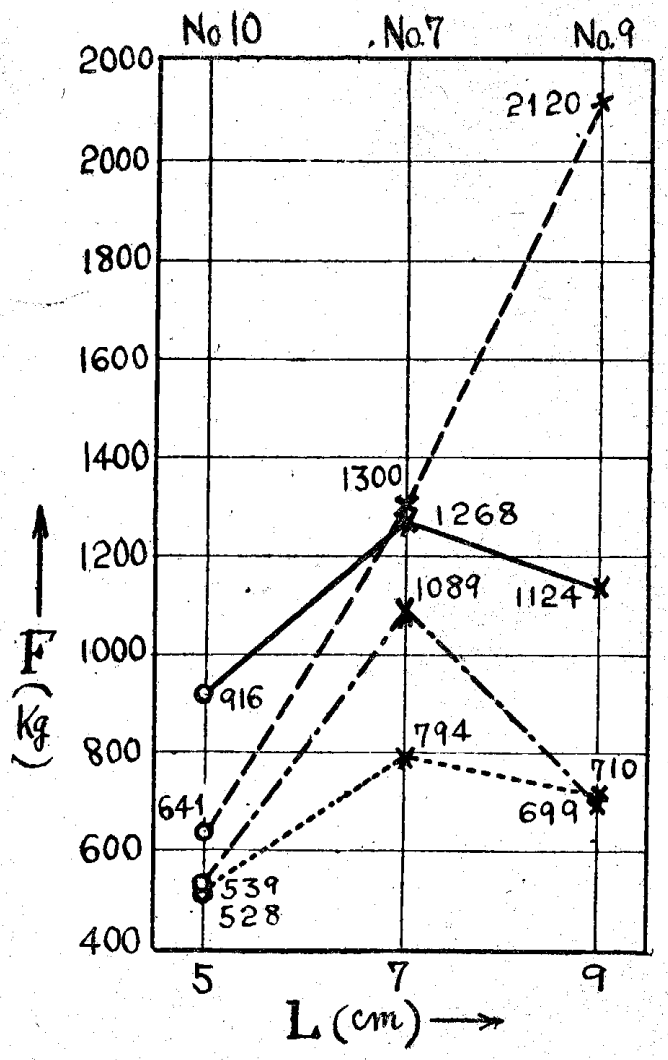

第 8 圖系 N

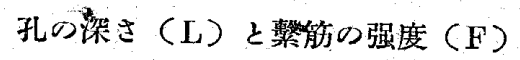




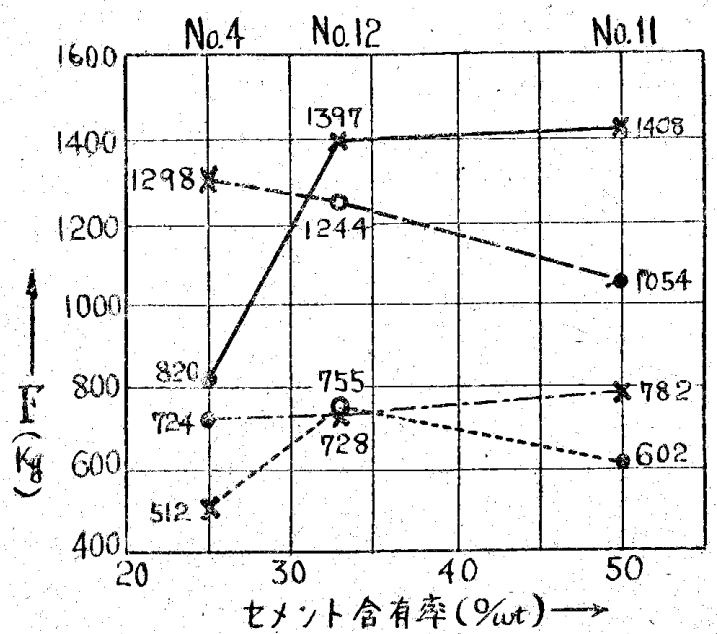

第 9 圖 系 モルタル調合々熬笳の强度 (F)

伏黙強度に於て 0.22 に過ぎなかつた。

\$4. 剪衒試騟

1) 試驗體

形狀:第 10 圖飞示す。

材料，製作法：曲げ試驗の時に同じ。

試驗體種類：試驗體の種類は第 3 表に示寸。

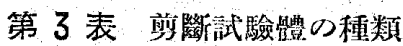

\begin{tabular}{|c|c|c|c|c|c|c|}
\hline 系 & 試驗の目的 & $\begin{array}{l}\text { 試驗體 } \\
\text { 番號 }\end{array}$ & 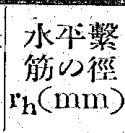 & 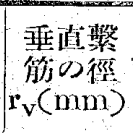 & 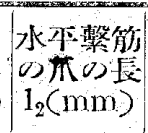 & 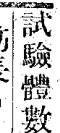 \\
\hline \multirow{3}{*}{ I } & \multirow{3}{*}{$\begin{array}{l}\text { 慗觔の徑の } \\
\text { 影響 }\end{array}$} & 1 & 3 & 3 & 2 & 2 \\
\hline & & 2 & 5 & 5 & 2 & 2 \\
\hline & & 3 & 9 & 9 & 2 & 2 \\
\hline \multirow{3}{*}{ II } & \multirow{3}{*}{ 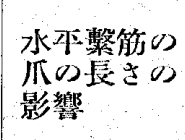 } & 4 & 5 & 5 & 0 & 1 . \\
\hline & & 2 & 5 & 5 & 2 & 2 \\
\hline & & 5 & 5 & 5 & 4 & 2 \\
\hline
\end{tabular}

各種 2 ケ宛製作しを。

2) 試騟方法

試驗方法の大要は第 11 圆に示士。中央部不材の彎 位はマルテンスの鏡及スケールで觀湘しした。

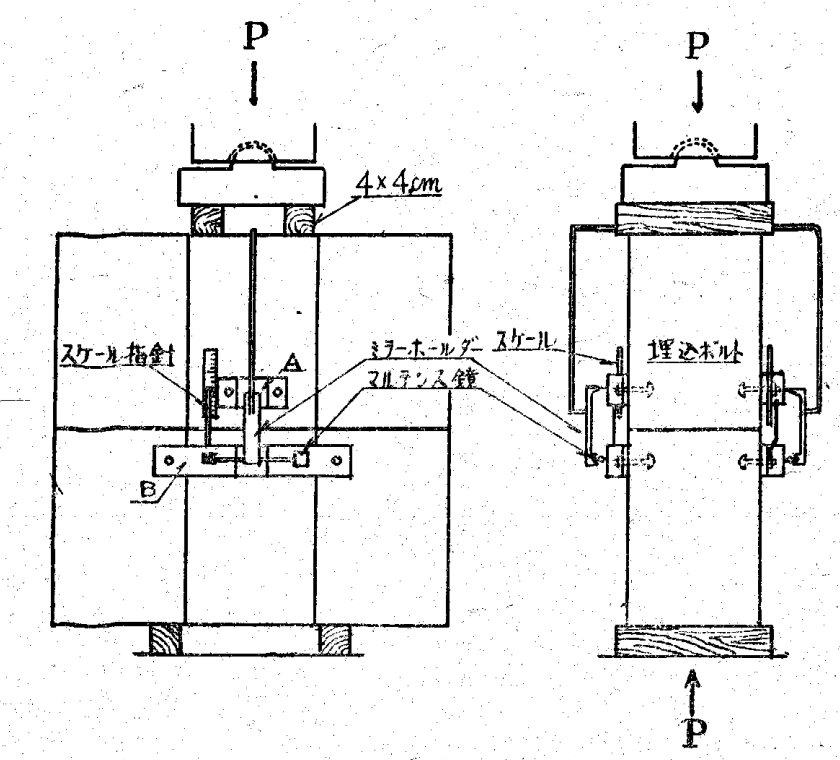

第 11 圆 剪斷試驗方法

Aは中央の不朴, Bは左右の石材に埋込ボル 卜で固定した緎板で，A，B 間の變位は，中 央不材の變位を示す。此ひ微小變位はマルテ ンスの鏡の迴轉により,より大きい變位は A， Bにそれぞ机固定してあるスケール及スケー 儿指釗の讀みに上り，湘起する。

3) 試驗結果

試驗結果性第 4 表及第 12１5 圖に示寸。

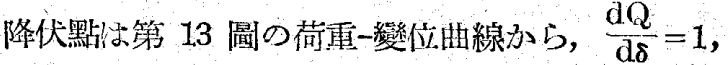
師ち $100 \mathrm{~kg}$ ，の菏車増加に對して $0.2 \mathrm{~mm}$ の變位の生 才゙る點展求めて定めた。

\section{§5. 結 論}

上述の試䌞結果を喻討して，結論として 下記の栐な強度計算法字得た。此等の公式 が如何なす法で導かれたかといふととは省 略し，結果の久記す。*

[曲げ強度]

此種の工法により繫結した石材 (邓はブ ロック)の曲げモーメントに對する破壞形 $-20^{\mathrm{cm}}+20^{\mathrm{cm}}+20^{\mathrm{cm}}-$ $+4 c m+f_{c m} \rightarrow$ 孔咩細

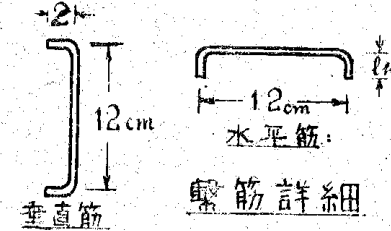

表声節

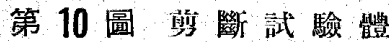

式は下記の如くである。

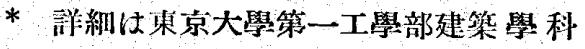
材料研究公內のドの報告中にある。 補强不造に關する研究 第 1 報 補品石造心構想 
第 4 表 剪斷試驗體破荟狀況

\begin{tabular}{|c|c|c|c|c|}
\hline 破 & 壃 & 原 & 因 & 試 驗 體 \\
\hline \multicolumn{4}{|c|}{ 繫筋が拔出した。の } & No. 4. \\
\hline \multicolumn{4}{|c|}{ 慗筋が刷切机たもの } & No. 1. \\
\hline \multicolumn{4}{|c|}{ 石材が破壊したもの } & No, 3, No, 5 \\
\hline \multicolumn{4}{|c|}{ 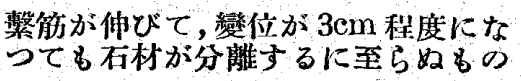 } & $\begin{array}{l}\text { No. } 1, \text { No. } 2 \text {, } \\
\text { No. } 5\end{array}$ \\
\hline
\end{tabular}

第 2 報曲げモーメントを受ける梁の豫備試驗

第 3報 曲げモーキントを受ける梁の第 2 回實驗 (其の 1 )

第 4 報 同 上（其の2）

第 5 報 剪斷力を受ける壁体の実驗

1. 媻腹の降伏

2. 䑖觔のボンド

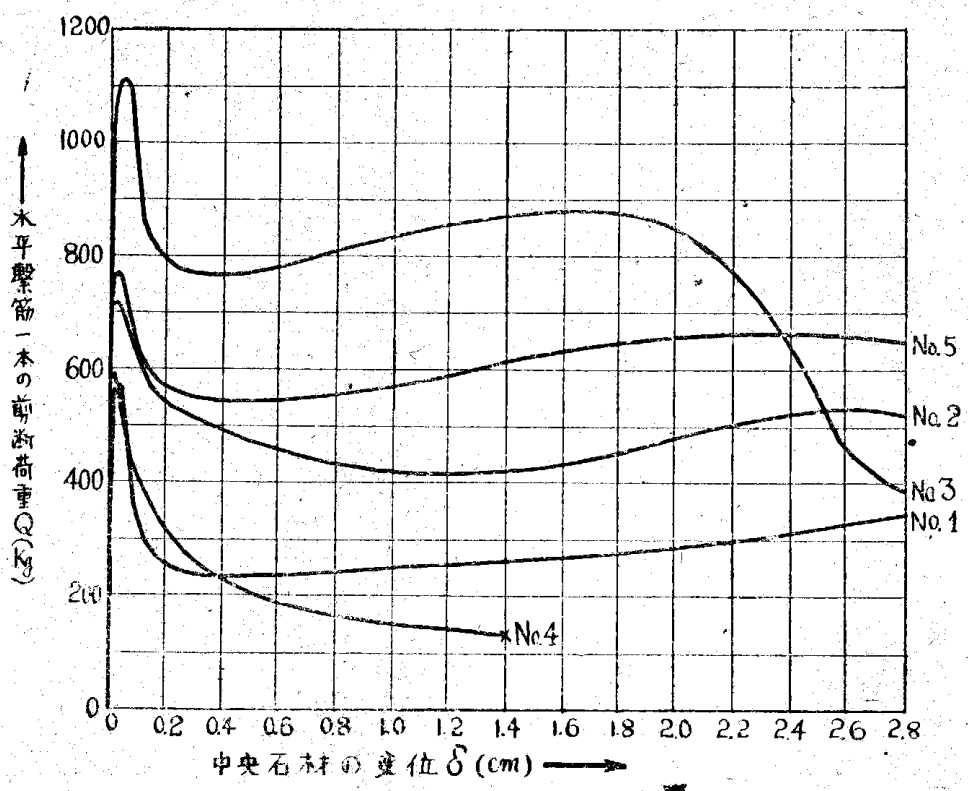

第 12 圖 㮍斷試驗に於ける荷重一變形曲綵

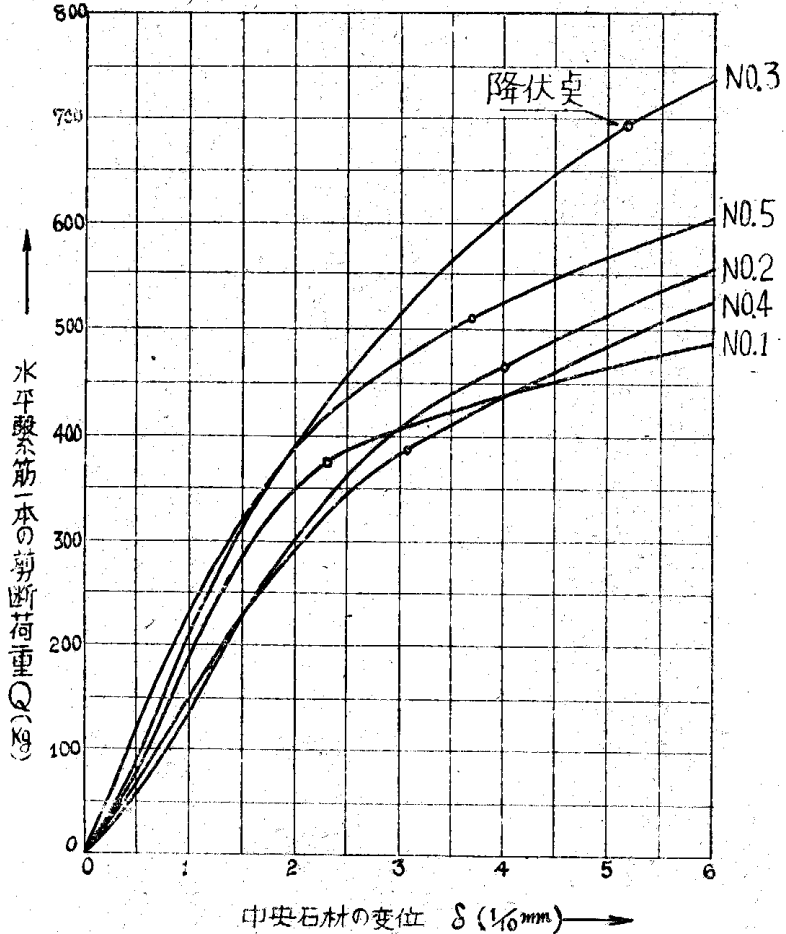

第 13 圖

煎斷試驗に於ける降伏點附近の荷重變形曲線

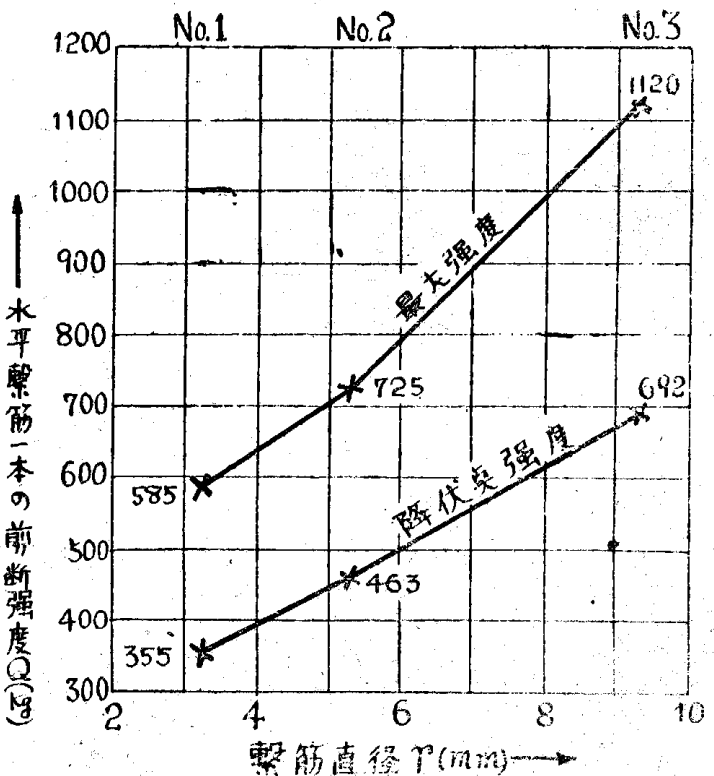

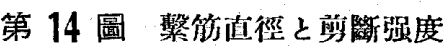




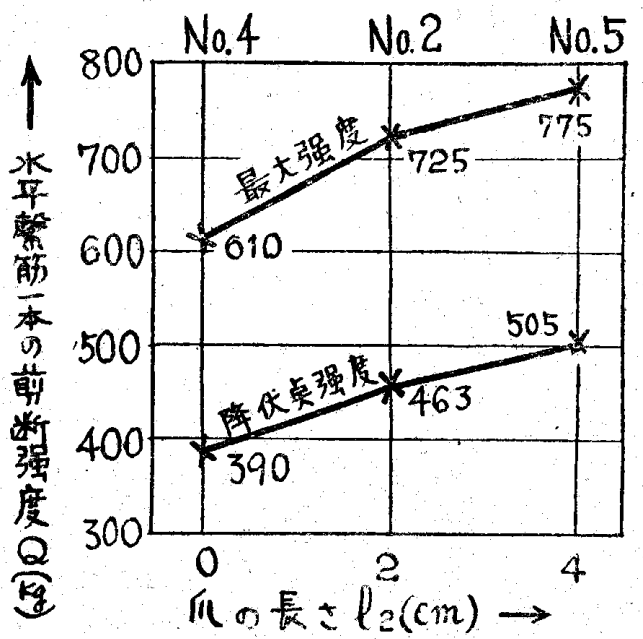

第 15 圖 爪の長さと剪斷强度

3. 孔埋モルタルのポンド

4. 石材の繫筋による引張破壊

5. 引張側石材の破壞

6. 樶縮側不材の破壊

各破壤形式に對する許容應力は下式厄算定出來る。 式中の許容應力度を定めるに當つては，短期荷重に對 し大凡實驗に於ける最大應力度の 0.5 , 降伏點應力度 の 0.6 の5ち, 小なる力学採り，長期條重に對して は短期荷重に對する值の $1 / 2$ 学採つた。

1. 繫筋の降伏

$$
\begin{aligned}
& \sigma=\frac{F}{a_{s}}, \quad F=\frac{M}{n j}, \quad j=\frac{7}{8} d \\
& \sigma=\frac{8 M}{7 n a_{s} d}
\end{aligned}
$$

ここに

$\sigma \cdot \cdots \cdot$. 㢣筋の許签引張應力度

短期描重に對し $\sigma=2400 \mathrm{~kg} / \mathrm{cm}^{2}$

長期荷重に對 $L ， \sigma=1600 \mathrm{~kg} / \mathrm{cm}^{2}$

$a_{s}$ …..繫能 1 本の斷面積

n......引張側繫管の數

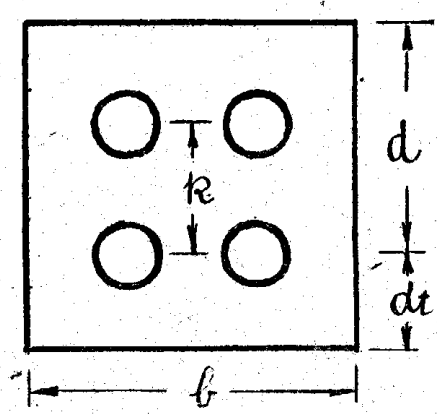

附圖 1
M…・出げモーメント ( $\mathrm{kg} \mathrm{cm})$

F ……引張側熬等 1 本 に㚪く力 (kg)

d......引張侧熬胼の中 心より, 厴縮侧不 材端迄の距離 $(\mathrm{cm})$ 附圖 1 參照

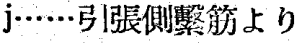
中立軸迄の距離 $(\mathrm{cm})$
註：今回心試驗に於ては繋觔の降伏で破壤したも のはないので，音通の銅筋コンクリートの部算力 法によつた。

2. 擊筋のボンド

$\mathrm{F}=\pi \gamma \mathrm{l}_{1} \tau_{1}+\pi \gamma \mathrm{l}_{2} \tau_{2}$

こご

$1_{1} \cdots \cdots \cdot$ 繫筋の埋込長さ (cm)

$1_{2} \cdots \cdots$ 繫筇の爪丿⿱丄𠃍冂卄八

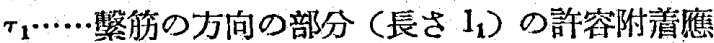

力度 $\left(\mathrm{kg} / \mathrm{cm}^{2}\right)$ 。附表 1 による。

$\tau_{2} \cdots \cdots$...盤筋の爪部分 (長さ $1_{2}$ ) の許容附清應力

度 $\left(\mathrm{kg} / \mathrm{cm}^{2}\right)$ 。附表 1 による。

\begin{tabular}{|c|c|c|}
\hline $\begin{array}{l}\text { 荷重 種数 } \\
\text { 調合(重量比) }\end{array}$ & $\begin{array}{l}\text { 長期荷重 } \\
\text { 几對し }\end{array}$ & $\begin{array}{l}\text { 短期荷重 } \\
\text { に對し }\end{array}$ \\
\hline $1: 1$ & $\tau_{1}=\tau_{2}=15$ & $\tau_{1}=\tau_{2}=30$ \\
\hline $1: 2$ & $\tau_{1}=\tau_{2}=17$ & $\tau_{1}=\tau_{2}=34$ \\
\hline $1: 3$ & $\tau_{1}=\tau_{2}=14$ & $\tau_{1}=\tau_{2}=28$ \\
\hline
\end{tabular}

附表 $1 \tau_{1}$ 及 $\tau_{2}$ 值

註：セメントは規格品とする。以下同じ。

3. 孔埋モルタルのボンド

$\mathrm{F}=\pi \mathrm{R}_{1} \times \tau_{\mathrm{c}}$

ここに

R......孔の植巠 (cm)

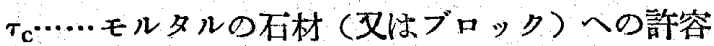
附着應力度 $\left(\mathrm{kg} / \mathrm{cm}^{2}\right)$ 。軟質凝灰岩に對与る $\tau_{c}$ は附表 2 による。

附表 2 軟質凝灰岩に對する $\tau_{\mathrm{c}}$

\begin{tabular}{c|c|c}
\hline \multirow{2}{*}{ モルタル } & \multicolumn{2}{|c}{$\tau_{\mathrm{c}}\left(\mathrm{kg} / \mathrm{cm}^{2}\right)$} \\
\cline { 2 - 3 } 媩合(重量比) & K長期荷重 & 短期荷重 \\
\hline $1: 1$ & 3.1 & K對 L \\
\hline $1: 2$ & 4.0 & 6.2 \\
$1: 3$ & 3.5 & 8.0 \\
\hline
\end{tabular}

4. 不材の繫筋による引張破壊

$\mathrm{L}<\mathrm{k}-\frac{\mathrm{R}}{2}$ の時

$\left.\mathrm{F}=\left\{\left(\mathrm{d}_{\mathrm{t}}+\mathrm{L}\right) \times \mathrm{b}-\mathrm{n} \boldsymbol{\pi}^{\prime} \frac{\mathrm{R}}{2}\right)^{2}\right\} \times \sigma_{\mathrm{t}}$

$\mathrm{L}>\mathrm{k}-\frac{\mathrm{R}}{2}$ の時

$$
F=\left\{\left(d_{t}+I_{1}\right) \times b-\left(n+n_{c}\right) \pi\left(\frac{R}{2}\right)^{2}\right\} \times \sigma_{t}
$$

ここに 
L......孔の深さ (cm)

$\mathrm{d}_{\mathrm{t}} \cdots \cdots$ 引張側の石材端から弓涱側孔の中心汽の距

離 (cm)。附圖 1 參照。

$\mathrm{k}$ ……引張側の孔と壓縮側の孔との中心距離 (cm)。附圖 1 參照。

b......石材の幅 $(\mathrm{cm})$ 。

$\mathrm{n}_{\mathrm{c}} \cdots \cdots \cdot$ 掼縮側の繫筋の數

$\sigma_{t} \cdots \cdots$ 石材の許容引張㕍力度 $\left(\mathrm{kg} / \mathrm{cm}^{2}\right)$

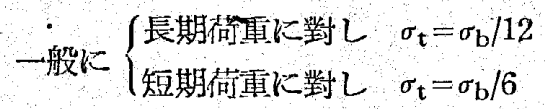

但L $\sigma_{b} \cdots \cdots$ 石材の曲破壊係數 $\left(\mathrm{kg} / \mathrm{cm}^{2}\right)$

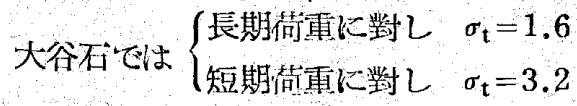

5. 引張側石材の破壞

$$
\mathrm{M}=\frac{\mathrm{bD}^{2}}{6} \sigma_{\mathrm{b}} \text { 許 }
$$

ここに

D....石材の厚さ $\left(d+d_{t}\right)(\mathrm{cm})$

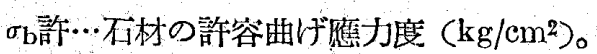

大谷石て胝 $\begin{array}{ll}\text { 長期荷重に對し } & \sigma_{\mathrm{b}} \text { 許 }=3 \\ \text { 短期荷車に對し } & \sigma_{\mathrm{b}} \text { 許 }=6\end{array}$

\section{6. 壓縮側石材の破壞}

$$
\mathrm{F}=\frac{\mathrm{bd}}{6} \sigma_{\mathrm{c}}
$$

ここに

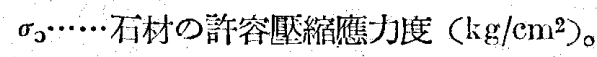

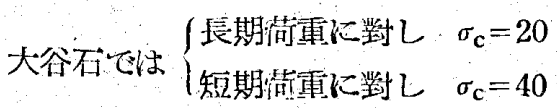

[剪落強度]

此種の工法に上り㢣結した石材（邓はブロック以下

同じ〉の剪㫀力に對子る破壊形式恃次の如くである。

1. 水平䌘筋のボンド

2. 水平繫筋の降伏

3. 水平繫筋による不材の破壞

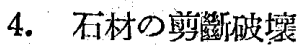

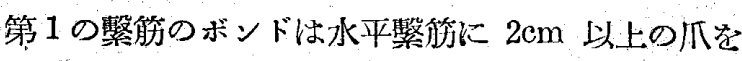
つければ起らないと考へてよい。そこで爪 $2 \mathrm{~cm}$ 以 上つけることにすれば考へなくてよい。 $2 \mathrm{~cm}$ 以上の 爪をつければ更に有利でること㤋るが，之を年最 的飞定めることは今㘣の䁈驗範園て泩不充分で女る。

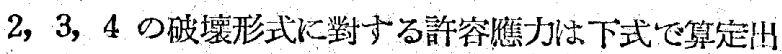
來る。式中の許容㷳力度と, 實驗值との關係恃, 曲计 應力度の場合と同樣でる。

2. 水平熬筋の降伏
1 本の水平慗解の許签剪歁應力 $\mathrm{Q}_{5}(\mathrm{~kg})$ は下 2 式 により得られる值の5ち，小なる方をとる。但し繫筫 は下記の條件焉满足しなくてはならない。

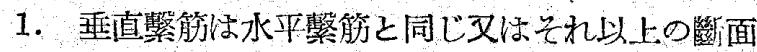
積を有すること。

2. 水平, 垂直㢣筋共飞 $2 \mathrm{~cm}$ 以上の爪先有するこ と。

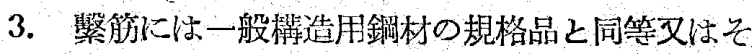
れ上上の強度及レング率を有する材料学用ひるこ と。

$$
\left\{\begin{array}{l}
Q_{s}=a r+b \\
Q_{s}=\pi \cdot{ }^{2} \sigma
\end{array}\right.
$$

ここに

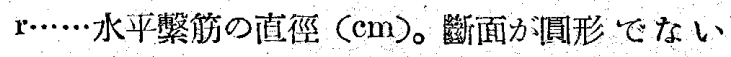
時には等面積の圆の直俓とする。

$\sigma, a, b \cdots \cdots . .$. 附表 3 の值をとる。

附表 $3 \sigma, a, b$ o值

\begin{tabular}{l|c|c|c}
\hline & $\sigma\left(\mathrm{kg} / \mathrm{cm}^{2}\right)$ & $\mathrm{a}(\mathrm{kg} / \mathrm{cm})$ & $\mathrm{b}(\mathrm{kg})$ \\
\hline 長期荷重に對し & 1400 & 170 & 45 \\
娪期荷重に對し & 2100 & 340 & 90 \\
\hline
\end{tabular}

上式をグラフにすれ恃，附阔 2 となる。

3. 水平㢣筋に上る不材の破壞

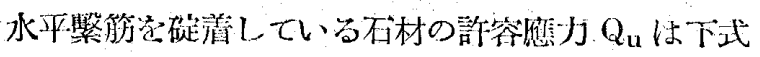
による。

$$
Q_{u}=(A-a) \sigma_{u}
$$

ここに

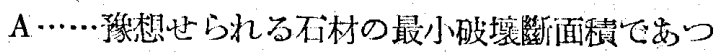

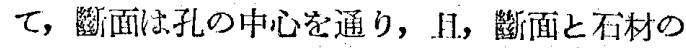

各陵とのなす僻 $45^{\circ}$ として部算寸る。

算例 1.

附踾 3. (a)，(b) k於

$$
\mathrm{AB}=\mathrm{BD}=\mathrm{AD}=21 \times \sqrt{2}=29.8 \mathrm{~cm}<30 \mathrm{~cm}
$$

故に

$$
A=(29.8)^{2} \times \frac{V \overline{3}}{4}=(29.8)^{2} \times 0.433=385 \mathrm{~cm}^{2}
$$

若し壁厚が $25 \mathrm{~cm}$ とすれば

$29.8>25$

故に路面虫（c）に示寸椾になり，その㭙には

$$
A=25 \times 6 \times \sqrt{2}=211 \mathrm{~cm}^{2}
$$

算例 2.

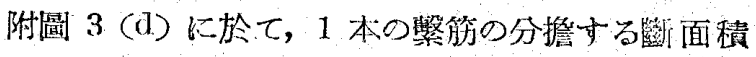
估 


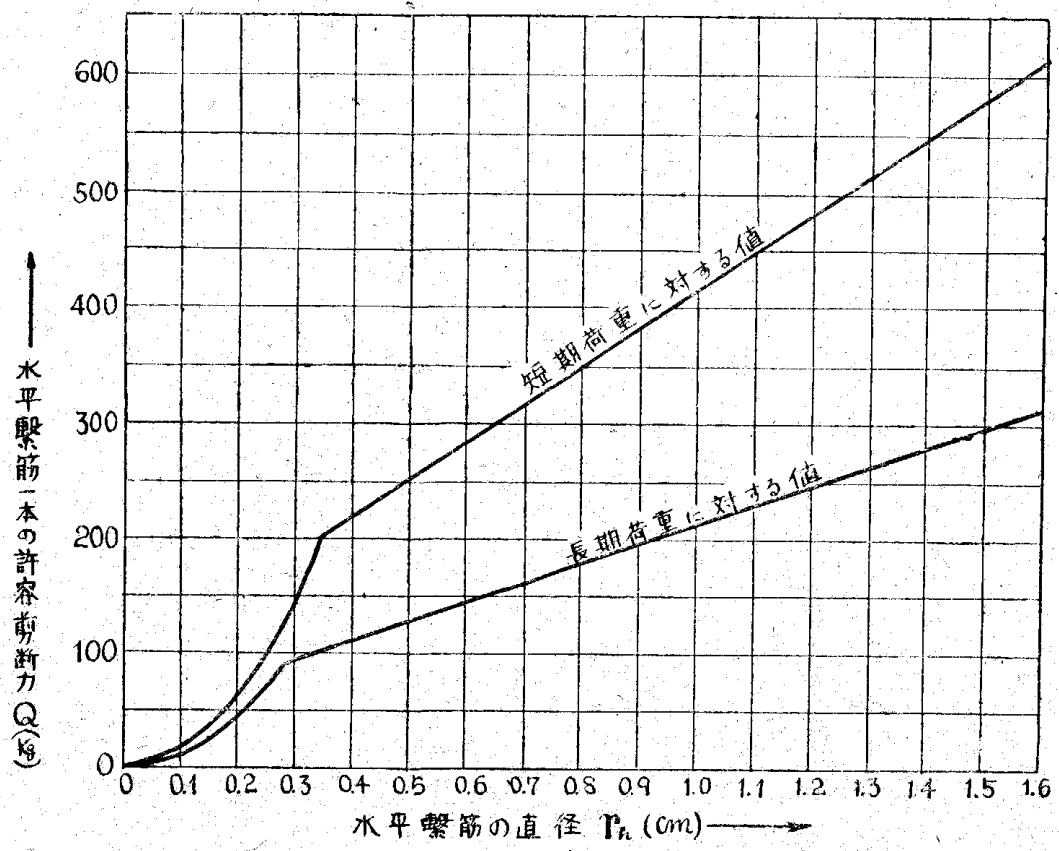

附圖 2 許容剪斷力算定用圆表
L……孔の深さ (cm)

$\sigma_{\mathbf{u}} \cdots \cdots$. 石材の許容應力度 $(\mathrm{kg} /$ $\left.\mathrm{cm}^{2}\right)$ ‘゙, 下記の值をとる。

長期行重以對し $\cdots \cdots \sigma_{\mathbf{u}}=$

$$
0.023 \sigma_{\mathrm{b}}\left(\mathrm{kg} / \mathrm{cm}^{2}\right)
$$

短期荷䨘长對 $ᄂ \cdots \cdots \cdot \sigma_{\mathbf{u}}=$

$$
0.046 \sigma_{\mathrm{b}}\left(\mathrm{kg} / \mathrm{cm}^{2}\right)
$$

但し $\sigma_{\mathbf{b}} \cdots \cdots$ 石材の曲げ強庋 $(\mathrm{kg})$ $\mathrm{cm}^{2}$ )

大谷石では

長期嗬重に對し …… $\sigma_{\mathbf{u}}=$

$0.46\left(\mathrm{~kg} / \mathrm{cm}^{2}\right)$

短期荷重に對し $\cdots \cdots \sigma_{\mathbf{u}}=$

$0.92\left(\mathrm{~kg} / \mathrm{cm}^{2}\right)$

\section{4. 石材の剪凿破壇}

石材の許容剪微應力は $Q_{\mathbf{q}}$ 下式に よる。

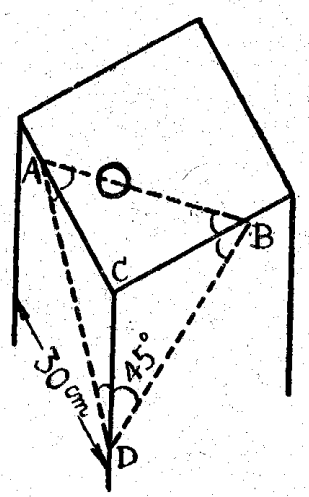

(a)

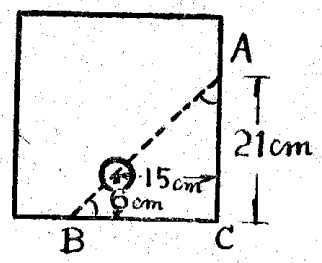

(b)

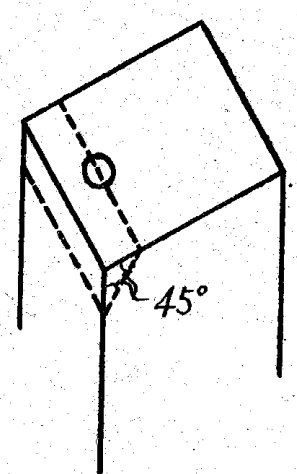

(C)

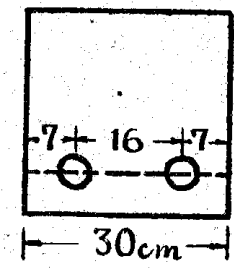

(d)
附圖 3

$$
A=(30 \times 6 \times \sqrt{2}) \times \frac{1}{2}=127 \mathrm{~cm}^{2}
$$

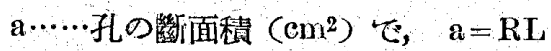

但し R......孔の直俓 $(\mathrm{cm})$

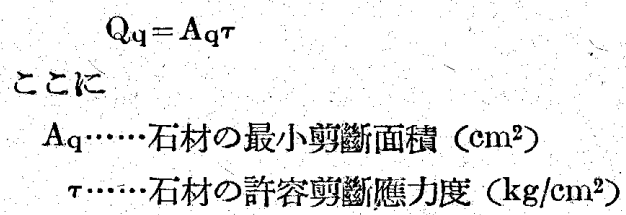

一般に，長期荷重に對し $\tau=0.1 \times \sigma_{\mathrm{b}}\left(\mathrm{kg} / \mathrm{cm}^{2}\right)$ 短期街重に對し $\tau=0.2 \times \sigma_{\mathrm{b}}\left(\mathrm{kg} / \mathrm{cm}^{2}\right)$

但し $\sigma_{\mathbf{b}} \cdots \cdots$ 不材の曲げ強度 $\left(\mathrm{kg} / \mathrm{cm}^{2}\right)$ 大欲石では

$$
\begin{aligned}
& \text { 長期荷重に對し } \quad \tau=2\left(\mathrm{~kg} / \mathrm{cm}^{2}\right) \\
& \text { 短期荷重に對し } \quad \tau=4\left(\mathrm{~kg} / \mathrm{cm}^{2}\right)
\end{aligned}
$$

以上モーメント及剪微力に對寸る本工法の強度計基 式を揭げたが，之によつて此種工法による組皘構造の 強度は略 マ確實に計算し得ると信ずる。勿論施工の不 层による強度低下なその時に應じて適當に考慮しなく てはならない。しかし此の工法に於ては目地のみに頼 る組皘法に比較すれば，施工不良による強度低下浽 らく極めて少いであらち。

§6. 䂧究筫及呼究期間

研究具一指 尊: 濱田 稔

$$
\begin{aligned}
& \text { 研究者 白山和久 } \\
& \text { 嗳 助 池时正二, 仾藤壽夫, 岡戶清一, } \\
& \text { 中西稀一郎 }
\end{aligned}
$$

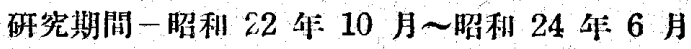

